\title{
STUDI KRITIS ATAS HADIS TENTANG RUKYAT DAN HISAB
}

\author{
Fuad Fansuri \\ Institut Agama Islam Negeri (IAIN) Samarinda
}

\begin{abstract}
:
The determination of the beginning and the end of Ramadan has a fundamental meaning for Muslims because it is associated with the implementation of fasting. In Indonesia, most of the year the issue becomes a polemic in society; it even tends to cause a conflict among Muslims. This paper focuses on the exposure of takhri $j$ hadith about rukyat and hisab on its practice on determining the beginning and the end of Ramadan in Indonesia.
\end{abstract}

Keywords: rukyat, hisab, takhrij Hadith

\begin{abstract}
Abstrak:
Penetapan awal dan akhir ramadan mempunyai arti yang sangat penting bagi umat Islam karena berkaitan dengan pelaksanaan ibadah puasa. Di Indonesia, hampir tiap tahun persoalan tersebut menjadi polemik di masyarakat, bahkan cenderung menimbulkan perpecahan di kalangan umat islam. Tulisan ini meniti beratkan pada pemaparan mengenai takhrij hadis tentang rukyat dan hisab serta pengamalannya terhadap penentuan awal dan akhir ramadan di Indonesia.
\end{abstract}

Kata Kunci: rukyat, hisab, takhrij Hadis 


\section{Pendahuluan}

Penetapan awal dan akhir Ramadan mempunyai arti yang sangat penting bagi umat Islam karena berkaitan dengan pelaksanaan ibadah puasa. Dalam hadis secara eksplisit dijelaskan tentang cara penetapannya yaitu dengan cara rukyat (pengamatan). Pada kondisi tertentu jika pengamatan tidak dapat dilakukan, diberikan alternatif dengan cara penyempurnaan hitungan bulan menjadi 30 hari. $^{1}$

Meskipun penetapan awal dan akhir Ramadan sudah ditentukan nabi, namun penerapannya di masyarakat ternyata tidak semudah yang dibayangkan. Di Indonesia, hampir tiap tahun persoalan tersebut menjadi polemik di masyarakat, bahkan cenderung menimbulkan perpecahan di kalangan umat islam. Tidak jarang masyarakat berbeda dalam pelaksanaan hari raya idul fitri maupun idul adha karena perbedaan interpretasi dalam melihat hadis penetapan awal dan akhir Ramadan tersebut.

Sebagian kalangan menganggap bahwa hadis penetapan awal dan akhir Ramadan hanya bersifat temporal dan kondisional di zaman nabi, sehingga saat ini tidak lagi dapat dijadikan pegangan untuk menetapkan datangnya bulan Ramadan. Mereka beralasan bahwa umat Islam pada waktu itu belum memiliki keahlian di bidang perhitungan bulan. ${ }^{2}$ Sedangkan sebagian lain menganggap bahwa hadis tersebut harus diamalkan sesuai dengan makna lahirnya.

\footnotetext{
${ }^{1}$ Ibn Hajar al-Asqalani, Fath al-Bari, Juz 4 (Kairo: Dar al-Hadis, 2004), h. 146.

${ }^{2}$ Dalam hadis diistilahkan dengan umat yang ummi, yaitu tidak pandai membaca dan menghitung.
} 
Fuad Fansuri, Studi Kritis atas Hadis tentang Rukyat... $\mid 99$

Proses melihat bulan di zaman nabi memang sangat sederhana, yakni cukup dengan mengamati matahari yang terbenam di hari ke-29. Jika setelah magrib bulan sabit (hilal) tidak terlihat maka bilangan bulan akan digenapkan 30 hari. Hal ini berbeda dengan keadaan umat Islam sekarang yang ilmu astronominya telah berkembang pesat sehingga datangnya bulan dapat diprediksi secara matematis jauh-jauh hari sebelumnya. Ilmu astronomi mutakhir diklaim sudah sangat akurat dalam melakukan perhitungan pergerakan bulan, bahkan kemungkinan terjadinya kesalahan penentuan awal bulan qamariah hanya 1 banding $3600 .^{3}$

Lebih jauh, perbedaan penetapan awal dan akhir Ramadan bukan hanya karena perbedaan interpretasi hadis, akan tetapi perbedaan tersebut juga terjadi karena perbedaan metode perhitungan. ${ }^{4}$ Sudah banyak karya tulis yang membahas mengenai perbedaan penggunaan metode tersebut, namun jarang-kalau boleh dikatakan tidak ada-yang membahas kualitas dan status ke-hujjahan hadis yang menjadi dasar dari masing-masing kelompok yang berbeda tersebut melalui penelitian takhrij al-hadis.

Berdasarkan latar belakang di atas, pokok masalah yang akan dikaji adalah "Bagaimana Studi Kritis atas Hadis tentang Rukyat dan Hisab”. Adapun sub-masalah yang akan dibahas adalah:

1. Bagaimanatakhrij hadis tentang rukyat dan hisab?

2. Bagaimana pengamalan hadis tentang rukyat dan hisab terhadap penentuan awal dan akhir Ramadan di Indonesia?

${ }^{3}$ Farid Ruskand, 100 Masalah Hisab dan Rukyat; Telaah Syariah Sains dan Teknologi (Bandung: Gema Insani Press, 1996), h. 15-16.

${ }^{4}$ Metode rukyat dan metode hisab mempunyai sasaran yang sama dalam penentuan awal dan akhir ramadan, yaitu hilal, namun beragamnya sistem perhitungan, metode dan kriteria yang digunakan menjadikan hasil pengamatannya berbeda satu sama lain. 
100 |RAusyan FiKR, Vol. 13 No. 1 Juni 2017: 97 - 118

\section{Pengertian Rukyat dan Hisab}

Rukyat secara bahasa mengandung makna aktifitas melihat secara langsung dengan mata kepala atau melihat dengan ilmu. ${ }^{5}$ Selanjutnya aktifitas yang dimaksud adalah mengamati visibilitas hilal, yakni penampakan bulan sabit yang nampak pertama kali setelah terjadinya konjungsi, khususnya hilal yang nampak sebagai tanda masuknya bulan suci Ramadan.Di dalam hadis, terdapat beberapa ungkapan yang menunjukkan hal tersebut, seperti صو امو الرؤيته atau لا تصوامو ا حتي تروا الهلال

Rukyat dapat dilakukan dengan mata telanjang atau dengan alat bantu optik seperti teleskopsebagaimana yang lazim dilakukan dewasa ini. Rukyat yang dilakukan dengan mata telanjang hampir mustahil dilakukan, khususnya di Indonesia, karena hilal hanya tampak setelah matahari terbenam dimana intensitas cahayanya sangat redup dibanding cahaya matahari serta ukurannya sangat tipis.

Adapun hisab secara harfiah berarti perhitungan. Meskipun dalam hadis tidak dikenal istilah hisab untuk menunjukkan makna perhitungan posisi bulan dalam menentukan awal bulan kalender hijriyah, khususnya bulan Ramadan, namun digunakan istilah lain untuk menunjukkan hal tersebut, seperti فاكملوا atau فاقدروا. Hal ini karena pada masa nabi, ilmu falak (astronomi) belum dikenal sehingga istilah hisab belum digunakan, meskipun dalam Alquran surah yūnus ayat 5 disebutkanbahwa Allah sengaja menjadikan matahari dan bulan sebagai alat menghitung tahun dan perhitungan lainnya. Penggunaan kata hisāb dalam Alquran juga terdapat dalam

${ }^{5}$ Ibn al-Manżur, Lisān al- 'Arab Jilid 4 (Cairo: Dār al-Hadis, 2003), h. 12. Bandingkan dengan Muhammad ibn Abì Bakr ibn 'Abd al-Qadir al-Rāzì, Muhktār al-Sahḥāh (Kairo: Dār al-Hađìs, 1424 H/2003 M), hlm. 133. 
Fuad Fansuri, Studi Kritis atas Hadis tentang Rukyat... |101

surah al-Rahmān ayat 5 , namun bukan dalam arti perhitungan posisi bulan untuk menentukan awal dan akhir Ramadan.

Dalam dunia Islam modern istilah hisab sering digunakan dalam ilmu falak (astronomi) untuk memperkirakan posisi Matahari dan bulan terhadap bumi. Posisi Matahari menjadi penting karena menjadi patokan umat Islam dalam menentukan masuknya waktu salat. Adapun posisi bulan diperkirakan untuk mengetahui terjadinya hilal sebagai penanda masuknya periode bulan baru dalam kalender Hijriyah.

\section{Takhrij al-Hadis tentang Rukyat dan Hisab}

Takhrij menurut bahasa berasal dari kata خرج yang berarti yang berarti tampak atau jelas. Takhrij secara bahasa juga berarti berkumpulnya dua perkara yang saling berlawanan dalam satu persoalan, namun secara mutlak, Takhrij diartikan oleh para ahli bahasa dengan arti mengeluarkan, (al-Istinbāt), melatih atau membiasakan, (al-Tadrib), dan menghadapkan (al-Taujih), tampak, (al-Iẓhār), dan jelas, (al-Ibrāz). ${ }^{6}$

Secara terminologi takhrij al-hadisadalah penulusuran suatu hadis melalui sumber asli yang diriwayatkan dengan sanad serta penjelasan tentang kualitas hadis tersebut ketika dibutuhkan. ${ }^{7}$ Hal yang senada dari ungkapan Syuhudi yang melihat bahwa takhrij merupakan penelusuran suatu hadis melalui kitab-kitab hadis sebagai sumber aslinya, dari kitab sumber tersebut dikemukakan secara lengkap mengenai matn dan sanad hadis yang

${ }^{6} \mathrm{Abū}$ Muhammad 'Abd al-Muhdi bin 'Abd al-Qādir al-Hādi. Tarīq alTakhrīj Hadìs Rasulullah 'Alaihi wasallam. Dār al-Ikhtiṣām: t.t. h.6.

${ }^{7}$ Sa'id ibn 'Abdillah Ā $l i$ Hamid, Turuq Takhrij al-Hadis (Cet. I; Riyad: 'Ulūm al-Sunnah, 2000), h. 7. 
102 |Rausyan FikR, Vol. 13 No. 1 Juni 2017: 97 - 118

bersangkutan. ${ }^{8}$ Dengan demikian, takhrijj al-hadis adalah penelusuran atau pencarian hadis dalam berbagai kitab hadis (sebagai sumber asli dari hadis yang bersangkutan), baik menyangkut materi atau isi (matan), maupun jalur periwayatan (sanad) hadis yang dikemukakan.Namun, untuk efisiensi penulisan, maka penulis membatasi pencarian hadis tentang rukyat dan hisab hanya terbatas pada kitab Bukhari, meskipun terdapat juga penukilan dari beberapa kitab-kitab hadis lain yang dapat dijadikan sebagai hadis penguat.

\section{Metode Penelusuran Hadis}

Sebagai langkah awal penelusuran tentang hadis rukyat dan hisab dalam kitab Bukhari, penulis menggunakan metode takhrīj dengan maud $\bar{u}^{‘}$ hadis. ${ }^{9}$ Adapun kitab yang dijadikan mu'jam dalam mencari hadis tentang rukyat dan hisab adalahmiftăh kunūz alsunnahkarya A.J. Weinsink. Setelah ditelusuri dalam kitab tersebut dengan tema/kata kunci الصوم, ditemukan bahwa hadis tentang rukyat dan hisab terdapat dalam kitab Bukhari (بخ); kitāb ke-30;bab kesebelas. ${ }^{10}$ Setelah melakukan pengecekan pada kitab yang dimaksud,penulis menemukan hadis tentang rukyat dan hisab berada pada urutanke-1906 dan ke-1909. Namun, untuk lebih fokusnya pembahasan, maka penulis memilih hadis ke-1906 sebagai objek kajian.Hadis riwayat Bukhari yang dimaksud dapat dilihat di bawah ini.

${ }^{8}$ M.Syuhudi Ismail, Metodologi Penelitian Hadis Nabi (Cet. I; Jakarta: Bulan Bintang, 1992), h.43.

${ }^{9}$ Metode takhrij hadis berdasarkan maud $\bar{u}^{‘}$ hadis adalah suatu metode yang berlandaskan pada tema tertentu dalam pencarian sebuah hadis. Metode ini memilik beberapa keistimewaan, diantaranya; melatih kemampuan dalam memahami makna hadis dan dapat mendeteksi hadis-hadis yang mirip, yang dapat digunakan sebagai hadis penguat.

${ }^{10}$ A. J. Weinsink, Miftạh Kunūz al-Sunnah(Lahore: Idārah Tarjamān alSunnah, 1978), h. 286. 
Fuad Fansuri, Studi Kritis atas Hadis tentang Rukyat... $\mid 103$

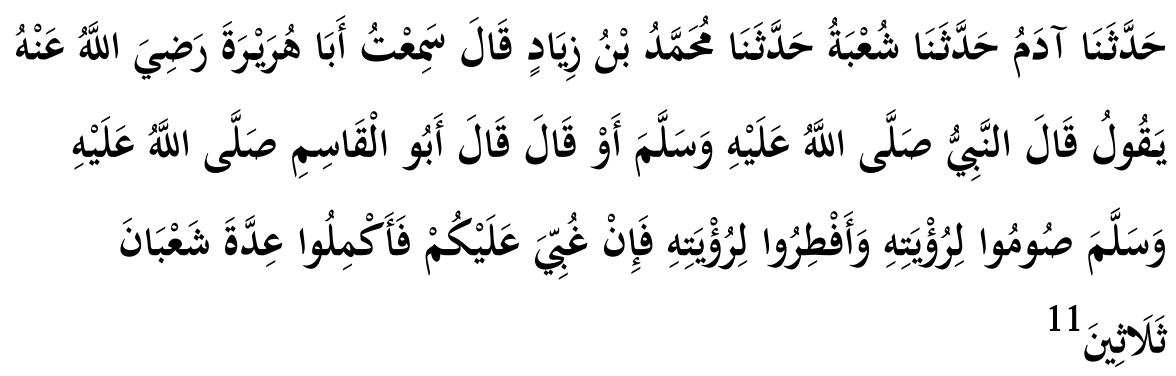

Terjemahnya:

"Telah menceritakan kepada kami Adam telah menceritakan kepada kami Syu'bah telah menceritakan kepada kami Muhammad bin Ziyad berkata, aku mendengar Abu Hurairah radliallahu 'anhu berkata; Nabi shallallahu 'alaihi wasallam bersabda, atau katanya Abu Al Qasim shallallahu 'alaihi wasallam telah bersabda: "Berpuasalah kalian dengan melihatnya (hilal) dan berbukalah dengan melihatnya pula. Apabila kalian terhalang oleh awan maka sempurnakanlah jumlah bilangan hari bulan Sya'ban menjadi tiga puluh."

\section{Hadis-hadis Pendukung}

Adapun hadis-hadis yang selafaldan semakna dengan hadis diatas sebagaimana yang terdapat pada kitab miftạh kunüz alsunnah adalah sebagai berikut:

a. Riwayat Muslim; kitāb 13; hadis ke-3 - hadis ke-20.

b. Riwayat Abu Daud; kitāb 14; bab 6-7.

c. Riwayat al-Turmuzi; kitāb 6; bab 2 dan bab 5 .

d. Riwayat al-Nasāi; kitāb 22; bab 8-13, 17, dan 37.

e. Riwayat ibnu Majah; kitāb 7; bab 7.

${ }^{11}$ Ibn Hajar al-Asqalani, Fath al-Bari, h. 146. 
104 |Rausyan FiKR, Vol. 13 No. 1 Juni 2017: 97 - 118

f. Riwayat al-Dārimī; kitab 4; bab 1-3.

g. Riwayat Malik; kitāb 18; hadis 1-3.

h. Riwayat Ahmad (terdapat banyak hadis)

\section{Kritik Sanad}

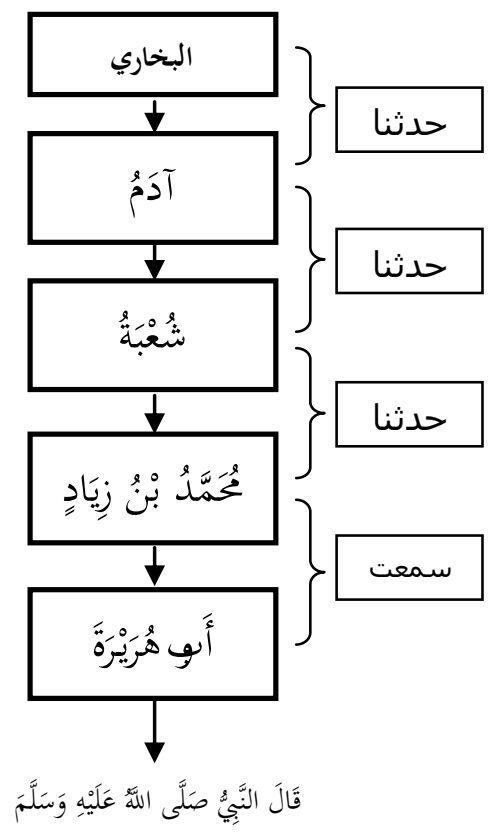

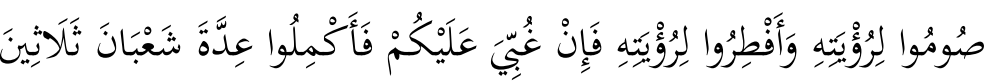


Fuad Fansuri, Studi Kritis atas Hadis tentang Rukyat... |105

Untuk melakukan kritik sanad hadis, perlu kiranya terlebih dahulu mengetahui acuan yang akan digunakan sebagai suatu standar. Acuan tersebut nantinya dapat dijadikan rujukan untuk menentukan sebuah hadis sahih atau tidak.Untuk hal di tersebut, acuan yang akan digunakan untuk melakukan kritik sanad hadis, sebagaimana juga banyak digunakan oleh para kritikus hadis adalah kaidah-kaidah kesahihan sanad hadis.

Kaitannya dengan kaidah kesahihan sanad hadis, Syuhudi Ismail telah menetapkan dua kaidah yang dapat dijadikan sebagai acuan; pertama kaidah mayor; dan kedua kaidah minor. ${ }^{12}$ Kaidah mayor terdiri dari beberapa kriteria; (a) sanadnya bersambung, (b) periwayatnya bersifat adil, (c) periwayatnya bersifat dabit, (d) terhindar dari kejanggalan, (e) terhindar dari cacat.Sedang kaidahkaidah minor yang muncul dari kaidah-kaidah mayor setelah diadakan penelahaan dengan seksama dapat disimpulkan sebagai berikut:

a. Kaidah minor dari sanad bersambung adalah muttasil, marfü' dan mahfüz.

b. Kaidah minor dari periwayat bersifat adil adalah beragama Islam, mukallaf, melaksanakan ketentuan agama, dan memelihara wibawa atau harga diri.

c. Kaidah minor dari periwayat yang bersifat dabit adalah hafal dengan baik hadis yang diriwayatkannya, mampu dengan baik menyampaikan hadis yang dihafalnya kepada orang lain, terhindar dari kejanggalan dan illat

Berdasarkan penelitian penulis terhadap rawi-rawi dalam hadis tentang rukyat dan hisab tidak ditemukan hal-hal yang dapat

\footnotetext{
${ }^{12}$ Syuhudi Ismail, Kaidah-Kaidah Kesahihan Sanad Hadis, (Jakarta: Bulan Bintang, 1995), h. 120.
} 
106 |RAusyan Fikr, Vol. 13 No. 1 Juni 2017: 97 - 118

menjadikan sanadnya tidak sahih sebagaimana kriteria-kriteria yang ditentukan oleh Syuhudi Ismail di atas. Hal ini dapat dilihat dari biografi rawi-rawi yang penulis simpulkan sebagai berikut:

a. Abu Hurairah (W. $57 \mathrm{H}$ )

Beliau adalah berasal dari kalangan shabat. Beliau lebih dikenal dengan julukannya dari pada nama sebenarnya. Abu Hurairah berasal dari Dausi, keturunan Daus bin Adnan bin Abdullah dan ayahnya bernama Umair

b. Muhammad bin Ziyad (W. $120 \mathrm{H}$ )

Mempunyai lengkap Muhammad bin Ziyad al Quraisyi. Ibrahim bin Hani' dari Ahmad berkata bahwa beliau adalah orang yang tsiqah. Demikian pula Ishaq bin Mansur dari Ibnu Mu'ayyan juga menyatakan bahwa beliau adalah orang yang siqah.

c. Syu'bah (W. $160 \mathrm{H})$

Nama lengkapnya adalah Shu'bah bin al-Hajjaj bin al-Ward. Abu Thalib dari Ahmad berkata bahwa Shu'bah adalah orang yang paling tetap dalam masalah hukum dan lebih mengetahui pada hadis serta tidak ada pada zamannya orang yang semisalnya dalam masalah hadis.

d. $\operatorname{Adam}($ W. $220 \mathrm{H})$

Beliau lahir di Baghdad dan tinggal di Asqalan hingga wafatnya. Beliau mempunyai nama lengkap Adam bin Abi Iyas. Abu Dawud, al-Ajili, ibnu Hibban, dan Ibnu Mu'ayyan menyatakan bahwa beliau adalah termasuk kalangan orang yang siqah.

Berdasarkan penjelasan di atas, maka dapat disimpulkan bahwa sanad hadis tentang rukyat dan hisab yang diriwayatkan oleh Bukhari adalah sahih. 
Fuad Fansuri, Studi Kritis atas Hadis tentang Rukyat... $\mid 107$

\section{Kritik Matan.}

Meskipun sebagian kritikus hadis telah menetapkan bahwa ketika sanad sebuah hadis dinilai sahih sesuai kriteria kesahihan sanad, secara otomatis matan hadis tersebut juga bernilai sahih, namun penulis menilai seseorang yang telah disepakati keadilan dan kedhabitannya belum tentu ia tidak pernah mengatakan suatu kebohongan.

Untuk mengetahui matan hadis yang mengandung syadz dan illat Syuhudi Ismail hadir dengan membawa istilah yang baru, yaitu kaidah mayor dan kaidah minor. Kaidah mayor dipahami sebagai kaidah pokok kesahihan hadis dan itulah yang disebutkan dalam defenisi hadis. Dengan kata lain, kaidah mayor matan hadis adalah; a) tidak ada syadz di dalamnya, b) tidak ada illat di dalamnya. Sedangkan tolak ukur untuk mengetahui syadz dan illatnya matan hadis, itulah yang disebut sebagai kaidah minor. Khusus untuk syadz matan hadis, kaidah minornya adalah : a) sanad hadis bersangkutan tidak menyendiri, b) matan hadis bersangkutan tidak bertentangan dengan matan hadis yang sanadnya lebih kuat, c) matan hadis bersangkutan tidak bertentangan dengan al-Qur'an, dan d) matan hadis bersangkutan tidak bertentangan dengan akal dan fakta sejarah. Sedangkan kaidah minor bagi matan hadis yang mengandung illat adalah: a) matan hadis tersebut tidak mengandung idräj (sisipan), b) matan hadis bersangkutan tidak mengandung ziyādah (tambahan), c) tidak terjadi maqlüb (pergantian lafazh atau kalimat) bagi matan hadis tersebut, d) tidak terjadi iḍtirāb (pertentangan yang tidak dapat dikompromikan) bagi matan hadis 
108 |Rausyan FikR, Vol. 13 No. 1 Juni 2017: 97 - 118

tersebut, e) tidak terjadi kerancuan lafazh dan penyimpangan makna yang jauh dari matan hadis tersebut. ${ }^{13}$

Berdasarkan penelitian singkat penulis terhadap matan hadis tentang rukyat dan hisab juga tidak ditemukan hal-hal yang dapat menjadikan matannya tidak sahih, sehingga dapat disimpulkan bahwa matan hadis tersebut adalah sahih.

\section{Fiqh al-Hadis.}

Fiqh al-hadis dalam penelitian sebuah hadis perlu dilakukan untuk menghindari pemahaman yang keliru terhadap makna hakiki sebuah hadis. Dalam hal ini, pendekatan pertama yang dipakai penulis adalah dengan meneliti aspek lugawiyyah alhadis, dimanahadis yang telah disebutkan di atas terdapat beberapa kata yang perlu dijelaskan maknanya, baik dari segi mufradātnya maupun segi balagahnya.

Pertama, kata perintah صوموا berasal dari fi'l mädiplip yang secara etimologi bermakna menahan. Sedangkan secara terminologi, puasa bermakna menahan diri dari segala hal yang membatalkan puasa sejak terbitnya matahari (waktu subuh) sampai terbenamnya matahari (waktu magrib). Adapun penggunaan kata perintah dalam hadis tersebut menunjukkan kewajiban berpuasa di bulan Ramadan. Namun demikian, kewajiban berpuasa di bulan Ramadan tidak serta merta dapat dilakukan tanpa diawali dengan aktifitas pengamatan bulan (rukyat). Demikian halnya kewajiban untuk berbuka (tidak berpuasa/lebaran) juga dikaitkan dengan aktifitas rukyat. Hal tersebut dapat dilihat dari lafal صوموالرؤيته وأفطروالرؤيته yang berarti, "berpuasalah karena melihat bulan, dan berbukalah karena

${ }^{13}$ Arifuddin Ahmad, Paradigma Baru Memahami Hadis Nabi,Refleksi Pemikiran Pembaruan Syuhudi Ismail (Cet. II; Jakarta: MSCC, 2005), h. 108. 
Fuad Fansuri, Studi Kritis atas Hadis tentang Rukyat... 109

melihat bulan". Kewajiban berpuasa yang dikaitkan dengan aktifitas rukyat juga disebutkan dalam al-Qur'an Q.S al-Baqarah: 185.

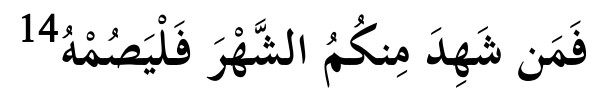

Terjemahnya:

"Barang siapa yang menyaksikan bulan, maka hendaknya ia berpuasa."

Kedua, kata روية berasal dari fi'l رأى yang menurut bahasa memiliki dua makna yang berbeda; 1) melihat dengan mata;2) melihat dengan ilmu pengetahuan. Kata رؤية bermakna penglihatan jika dalam kalimatnya terdiri dari satu maf'ul dan bermakna pengetahuan jika dalam kalimatnya terdiri dari dua maf'ul. ${ }^{15}$ Selanjutnya, رأى dalam ilmu balagah dapat bermakna haqiqah dan majaz. Haqiqah adalah penggunaan kata sesuai dengan makna aslinya, seperti contoh; "saya melihat bulan dari kamar" sehingga dalam hal ini, penglihatan yang dimaksud adalah penglihatan yang sesuai dengan makna aslinya. Sedangkan majaz adalah penggunaan katayang tidak menunjukkan kepada arti yang sebenarnya sebagaimana yang dikehendaki suatu bahasa, seperti contoh; "saya melihat bulan duduk di kamar" sehingga kata melihat disini tidak dapat diartikan sebagaimana makna aslinya, namun dialihkan kepada makna sesuatu yang menunjukkan keindahan seperti halnya keindahan bulan. Oleh karena itu, berdasar pada penjelasan tersebut, kata رؤية dalam hadis Bukhari memiliki makna haqiqah yang sesuai dengan makna aslinya yaitu melihat dengan mata kepala.

\footnotetext{
${ }^{14}$ Kementerian Agama RI, Al-Qur'an dan Terjemahnya (Jakarta: PT. Tehazed, 2010), h. 397.

${ }^{15}$ Ibn al-Manżur, Lisān al- 'Arab Jilid 4 (Cairo: Dār al-Hadis, 2003), h. 12.
} 
110 |Rausyan FikR, Vol. 13 No. 1 Juni 2017: 97 - 118

Ketiga, kata غبي bermakna samar. ${ }^{16}$ Aktifitas penglihatan sebagaimana yang disyaratkan, diakui oleh nabi sangat tergantung pada kemampuan seseorang dalam melakukan pengamatan dan kondisi alam yang ada disekitarnya, sehingga dalam hal ini nabi mengaitkannya dengan huruf إن الشرطية, yang berarti; "jika tertutup -karena awan atau penghalang lain-, maka أكملوا عدة ثلاثين (sempurnakan bulan sya'ban 30 hari)". Dengan demikian, kewajiban puasa Ramadan juga terkait dengan perhitungan bulan sya'ban jika terdapat kondisi yang menghalangi seseorang melihat bulan/hilāl sebagai syarat awal dalam penentuan awal bulan Ramadan.

Meskipun secara lahiriah, melalui hadis rukyat dan hisab Rasulullah saw. memerintahkan umatnya memulai puasa dan berbuka berdasarkan rukyat, dan apabila terhalangi oleh mendung atau semisalnya maka dengan melengkapkan bilangan sya'ban menjadi tiga puluh hari. Namun, pada masa sekarang ini ilmu pengetahuan telah mengalami kemajuan, pengertian rukyat mengalami pergeseran. Ada yang memaknainya tetap seperti semula, yaitu rukyat bial-fi'l dan ada yang memaknai dengan rukyat bi al- 'ilm, yaitu melihat hilal dengan ilmu pengetahuan (hisab). ${ }^{17}$

Sejarah panjang ilmu hisab pada gilirannya dapat menghasilkan metode dan sistem perhitungan yang beragam. Hal itu disebabkan oleh adanya sistem atau metode yang tetap dipegangi oleh segolongan orang. Jika diperinci maka hal tersebut terbagi menjadi tiga, yaitu: ${ }^{18}$

\footnotetext{
${ }^{16}$ Ibn al-Manżur, Lisān al-'Arab Jilid 6 (Cairo: Dār al-Hadis, 2003), h. 571.

${ }^{17}$ Ibn al-Manżur, Lisān al- 'Arab, h. 12.

${ }^{18}$ Departemen Agama, Almanak Hisab Ru'yah (Jakarta : Proyek Pembinaan Badan Peradilan Agama Islam, 1981), h. 99-100.
} 
Fuad Fansuri, Studi Kritis atas Hadis tentang Rukyat... |111

1. Kelompok yang berpijak pada sistem ijtima' yang menetapkan awal bulan berdasarkan kepada waktu kapan ijtima' itu terjadi. Jika ijtima' terjadi sebelum saat matahari terbenam, sejak matahari terbenam itulah bulan mulai masuk. Akan tetapi jika ijtima' terjadi setelah matahari terbenam, hari berikutnya belum masuk bulan baru.

2. Kelompok yang berpegang pada posisi hilal di atas ufuk. Penetapannya dilakukan berdasarkan ketentuan, jika pada saat matahari terbenam posisi hilal menurut perhitungan sudah berada di atas ufuk, sejak matahari terbenam, bulan baru mulai dihitung.

3. Kelompok yang berpegang pada imkān alru'yah.Kelompok ini mengemukakan bahwa masuknya awal bulan baru/posisi hilal pada saat matahari terbenam harus ada pada ketinggian tertentu sehingga memungkinkan untuk diadakan pengamatan.

Dari rukyat dan hisab pula, muncul sebuah perbedaan pemahaman mengenai cara melihat hilal dan perbedaan matla', sehingga dapat menimbulkan perbedaan penentuan hari. Mengenai matla' atau tempat melihat hilal, secara garis besar terdapat beberapa pendapat, yaitu:

\section{Jumhur ulama}

Di antara mereka adalah Imam Ahmad dan Abu Hanifah yang menyatakan bahwa jika hilal telah terlihat di suatu negeri maka wajib bagi seluruh kaum muslimin untuk berpuasa.Abdurrahman al-Jaziri menjelaskan apabila ru'yatul hilal telah terbukti atau terlihat disanalah satu negeri, maka negeri-negeri yang lain harus mengikuti. Dari segi pembuktiannya tidak ada 
112 |Rausyan FiKR, Vol. 13 No. 1 Juni 2017: 97 - 118

perbedaan antara negeri yang dekat dengan negeri yang jauh jika kabar ru'yatul hilal itu memang telah sampai kepada mereka secara terpercaya. Di sini tidak diperhatikan lagi perbedaan mathla' hilal secara mutlak. Demikian pendapat Abu Hanifah, Maliki dan Ahmad bin Hanbal. Para ulama ini mengemukakan dalil :

a. Al-Qur'an surat al-Baqarah ayat 185 .

b. Hadis Rasulullah saw.

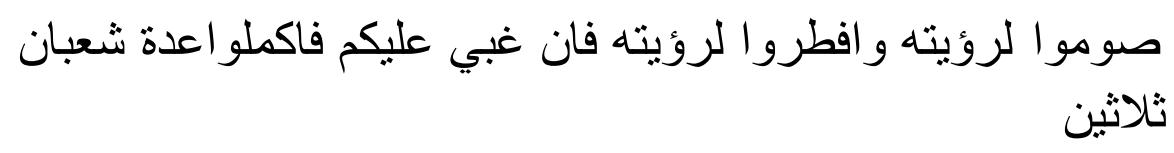

"Berpuasalah karena melihat hilal dan berbukalah (berhari raya) karena melihatnya."

Menurut pendapat ini pada dasarnya khitab yang terdapat pada hadis tersebut mengandung pengertian umum untuk seluruh kaum muslimin dan bukan sebagian dari mereka.

2. Syafi'iyah

Golongan ini berpendapat bahwa setiap negeri melihat hilal di tempat masing-masing. Mereka beralasan bahwa khitab hadis rukyat dan hisab bersifat relatif atau nisbi.Maka, menurut pendapat ini hadis tersebut menunjukkan bahwa perintah puasa dan berhari raya diperuntukkan orang yang melihat hilal di daerahnya sendiri. Adapun orang lain yang tidak mendapati hilal di daerahnya, maka yang sedemikian tidak berlaku. Dengan kata lain golongan Syafi'iyah berpendapat apabila ru'yatul hilal di suatu daerah telah terbukti, maka atas pembuktian ini penduduk yang terdekat di sekitar daerah tersebut wajib berpuasa. Ukuran kedekatan ini dihitung menurut kesamaan mathla', yaitu jarak antara keduanya 
Fuad Fansuri, Studi Kritis atas Hadis tentang Rukyat... |113

kurang dari 24 farsakh. Adapun penduduk daerah yang jauh maka mereka tidak wajib berpuasa dengan ru'yat ini, karena terdapat perbedaan mathla'. ${ }^{19}$

Dengan demikian menurut pendapat ini hukumnya mengikat pada wilayah sekitar daerah yang berdekatan itu. Sedangkan di luar jarak tersebut tidak terikat hukum rukyatul hilal. Dasar pendapat ini selain hadis di atas adalah qiyas perbedaan waktu shalat pada tiap wilayah dan juga pendekatan logika. ${ }^{20}$

\section{Pendapat Ketiga}

Golongan ini menyatakan apabila suatu daerah mathla'nya berbeda dengan negara lain, maka masing-masing daerah memiliki rukyah hilal (penentuan awal dan akhir bulan) sendiri-sendiri. Dan apabila mathla'nya sama (tidak berbeda), maka bagi siapa saja yang belum melihat hilal wajib mengikuti ketetapan rukyah hilal tempat lain. Dengan kata lain pendapat ini hampir sama dengan pendapat kedua, hanya saja tidak dibatasi oleh teritorial negara, sehingga dimana negara yang jaraknya berjauhan harus melihat hilal di tempat masing-masing, dan tidak untuk negera yang berdekatan. ${ }^{21}$ Mereka yang berpendapat demikian menggunakan dalil surat al-Baqarah ayat 185 sebagaimana yang digunakan oleh pendapat pertama. Tapi menurut pendapat ini, pada dasarnya ayat ini tidak dimaksudkan rukyahnya setiap orang, tapi yang dimaksudkan tempat dimana hilal dapat dilihat dan setiap tempat yang mathla' hilalnya sama.Adapun hadis "Berpuasalah karena melihat hilal dan berbukalah (berhari raya) karena melihatnya" 550.

${ }^{19}$ Abdurrahman al-Jaziri, al-Fiqh 'ala al-Madzahib al-Arba'ah, Juz I, hal.

${ }^{20}$ Dr. Wahbah al-Zuhaili, al-Fiqh al-Islami wa Adillatuhu, Juz I,hal.142.

${ }^{21}$ Lihat komentar Ibnu Qatadah di kitab al-Mughni, Juz IV,hal. 328. 
diartikan bahwa setiap orang yang berada disuatu daerah yang mathla' hilalnya tidak sama dengan orang yang melihat hilal maka pada saat itu hukum berpuasa atau berhari raya tidak berlaku baginya. Pendapat ini juga menyatakan bahwa penentuan bulan seperti penentuan hari, maka ketika suatu daerah tertentu berbeda dalam berpuasa dan berbuka dalam setiap bulannya, dan pada dasarnya kaum muslim sepakat bahwa dengan perbedaan waktu akan membawa dampak yang lain. Dengan demikian bagi yang tinggal di daerah bagian timur maka berpuasa sebelum mereka yang berada di bagian barat.

\section{Pendapat Keempat}

Golongan ini menyatakan bahwa perkara ini diserahkan pada waliyul amri (pemerintah). Kapanpun pemerintah menentukan wajibnya puasa dan berbuka yang didasarkan pada ketentuan syara', maka pada saat itu juga wajib bagi kaum muslim mengikutinya.

\section{Natijjah al-Bahs}

Sebagaimana telah disebutkan sebelumnya bahwa dalam hadis tentang rukyat dan hilal yang terdapat dalam kitab Bukhari tidak terdapat hal-hal yang dapat mengurangi kualitas hadis tersebut, baik dari segi sanad maupun dari segi matan sesuai dengan kriteria-kriteria yang telah ditetapkan oleh para kritikus hadis, sehingga dapat disimpulkan bahwa hadis tentang rukyat dan hisab dalam kitab sahih Bukhari adalah sahih dan wajib diamalkan sebagai sebuah syariat agama.

Namun demikian, persoalan muncul dalam pengamalan hadis tentang rukyat tersebut; apakah metode rukyat melalui aktifitas melihat bulan secara mata kepala atau alat bantu teropong masih 
Fuad Fansuri, Studi Kritis atas Hadis tentang Rukyat... |115

dapat dijadikan acuan untuk menentukan masuknya bulan kalender hijriyah, dimana kondisi geologis (alam) yang sudah jauh berubah dibanding kondisi di zaman nabi, juga perkembangan ilmu pengetahuan yangsangat pesat khususnya di bidang astronomi yang sudah dapat mendeteksi posisi bulan jauh-jauh hari sebelumnya.

Dalam hal ini, penulis tidak menekankan metode mana yang lebih sah untuk digunakan, namun dalam penetapan awal dan akhir Ramadan terdapat nilai jamă $\bar{i}$ (persatuan umat islam) dalam pelaksanaan ibadah puasa dan lebaran yang patut jadi pertimbangan. Oleh karena itu, guna mewujudkan persatuan, penulisberanggapan perlunya penetapan hakim/mufti, khususnya di Indonesia, yang memiliki kredibilitas dan ditopang dengan payung hukum yang kuat, juga memiliki independensi tanpa memihak kepada golongan tertentu.Selama ini, perselisihan penetapan awal dan akhir bulan Ramadan di Indonesia ditengarai terjadi karena Kementerian Agama sebagai penentu kebijakan hanya mewakili kepentingan golongan tertentu saja.Namun, apabila hal tersebut tidak dapat dilakukan hendaknya masyarakat tetap menjaga pluralisme dalam persatuan. Karena masalah ini adalah masalah fiqih yang memungkinkan berbeda.

\section{Kesimpulan}

Setelah dilakukan penelitian takhrij hadis tentang rukyat dan hilal yang terdapat dalam kitab Bukhari tidak terdapat hal-hal yang dapat mengurangi kualitas hadis tersebut, baik dari segi sanad maupun dari segi matan sesuai dengan kriteria-kriteria yang telah ditetapkan oleh para kritikus hadis. Begitupula dalam segi pemahaman/fiqh al-hadis, berdasarkan penelitian kosa-kata maupun penelitian ilmu balagah tidak terdapat hal yang mengharuskan pengalihan pemaknaan dari hakikah kepada majasi, sehingga dapat disimpulkan bahwa hadis tentang rukyat dan hisab dalam kitab 
116 |RAusyan FiKR, Vol. 13 No. 1 Juni 2017: 97 - 118

sahih Bukhari adalah sahih dan wajib diamalkan sebagai sebuah syariat agama.

Metode rukyat melalui aktifitas melihat bulan secara mata kepala atau alat bantu teropong tidak dapat dijadikan sebagai satusatunya acuan untuk menentukan masuknya bulan kalender hijriyah, karena kondisi geologis (alam) yang sudah jauh berubah dibanding kondisi di zaman nabi, juga perkembangan ilmu pengetahuan yang sangat pesat khususnya di bidang astronomi yang sudah dapat mendeteksi posisi bulan jauh-jauh hari sebelumnya. Dalam penetapan awal dan akhir Ramadan terdapat nilai jamá' $\bar{i}$ (persatuan umat islam) dalam pelaksanaan ibadah puasa dan lebaran yang patut jadi pertimbangan. Keberagaman dalam beragama memang merupakan sebuah keniscayaan, namun upaya penyelesaian dalam rangka mewujudkan keseragaman pandangan harus senantiasa diusahakan. Apalagi, masalah penetapan awal dan akhir Ramadhan di samping merupakan masalah ibadah juga masalah sosial. 
Fuad Fansuri, Studi Kritis atas Hadis tentang Rukyat... |117

\section{Daftar Pustaka:}

al-'Asqalāni, ibn Hajar.Fath al-Bari.Juz 4.Kairo: Dar al-Hadis, 2004.

Abū Muhammad 'Abd al-Muhdi bin 'Abd al-Qādir al-Hādì. Tarīiq al-Takhrij Hadis Rasulullah 'Alaihi wasallam. Dār alIkhtișām: t.t.

Ahmad, Arifuddin.Paradigma Baru Memahami Hadis Nabi,Refleksi Pemikiran Pembaruan Syuhudi Ismail. Cet. II; Jakarta: MSCC, 2005.

al-Jazirìi, 'abd al-Raḥmān, al-Fiqh 'ala al-Mażāhib al- 'arba'ah, Juz I.

Departemen Agama, Almanak Hisab Ru'yah. Jakarta: Proyek Pembinaan Badan Peradilan Agama Islam, 1981.

Ibn al-Manżur, Lisān al- 'Arab Jilid 4. Cairo: Dār al-Hadis, 2003. , Lisān al- 'Arab Jilid 6. Cairo: Dār al-Hadis, 2003.

Ismail, Syuhudi.Metodologi Penelitian Hadis Nabi. Cet. I; Jakarta: Bulan Bintang, 1992.

, Kaidah-Kaidah Kesahihan Sanad Hadis. Jakarta: Bulan Bintang, 1995.

Kementerian Agama RI, Al-Qur'an dan Terjemahnya. Jakarta: PT. Tehazed, 2010.

Ruskand,Farid. 100 Masalah Hisab dan Rukyat; Telaah Syariah Sains dan Teknologi. Bandung: Gema Insani Press, 1996.

al-Rāzì, Muhammad ibn Abī Bakr ibn 'Abd al-Qadir. Muhktār alSaḥ̆āh, Kairo: Dār al-Hadìs, 1424 H/2003 M. 
118 |Rausyan FiKR, Vol. 13 No. 1 Juni 2017: 97 - 118

Sa'id ibn 'Abdillah Ā $\bar{i}$ Hamīd, Turuq Takhrīj al-Hadis. Cet. I; Riyad: 'Ulüm al-Sunnah, 2000.

Weinsink, A. J. Miftāḥ Kunūz al-Sunnah. Lahore: Idārah Tarjamān al-Sunnah, 1978.

Wahbah al-Zuhaili, al-Fiqh al-Islami wa Adillatuhu, Juz I,hal.142. 